\title{
POLIGAMI: DARI FIQH HINGGA PERUNDANG-UNDANGAN
}

\author{
Atik Wartini \\ Pengiat kajian Hukum Islam Baitul Hikmah Jogjakarta \\ e-mail: reank_bae@yahoo.com
}

\begin{abstract}
Abstrak. Kajian poligami tidak pernah selesai, selalu saja ada pro dan kotra, dalam penelitian ini kajian poligami menitikberatkan pada kajian perundang-undangan, telaah figh, serta telaah hadis, dan pandangan beberpa sarjana kontemporer berkaiatan dengan isu poligami. Walaupun hanya sekedar deskripsi tentang poligami dari berbagai pandangan aturan, pada titik pentingnya adalah sikap penulis terhadap fenomena poligami di indonesia. Hukum yang bersifat normatif agar melahirkan ketegasan dalam sosila masyarakat menjadi penting dalam kajian ini. Pedekatan normatif sangat kental dalam tulisan ini, karena data yang digunakan masih berlandaskan kajian normatif. Terlepas dari itu pendekatan normatif dalam kajian ini menjadi salah satu pertimbangan dalam menyelesaikan por dan kontra dalam isuisu poligami.
\end{abstract}

Abstract. Studies on polygamy is never finished, there's always pro and contra, in this study, the study of polygamy is focused on the study of law, figh study, and the study of hadith, and the view of some contemporary scholars on the issue of polygamy. Although just a description of the polygamy of the various rules, at the point of importance is the author's attitude towards the phenomenon of polygamy in Indonesia. Normative law that gives firmness in social life becomes important in this study. Normative approach is very thick in this paper, because the data used is based on a normative study. Regardless of the normative approach in this study to be one consideration in completing pro and contra on polygamy issues.

Kata Kunci: Poligami, Hukum Islam, sarjana hukum Islam. 


\section{PENDAHULUAN}

Dewasa ini kondisi masyarakat menunjukkan perubahan yang pesat. Perubahan tersebut menimbulkan konsekuensi permasalahan yang sangat rumit dan memerlukan benang merah yang pas untuk menyelesaikannya. Harus disadari bahwa sebuah solusi yang dicetuskan harus mempertimbangkan aspek sosial, ekonomi, budaya, agama, medis, dan geografis masyarakat setempat, maka tak jarang semua pakar dari berbagai aspek ikut turun tangan untuk memikirkan jalan keluarnya. Diantara permasalahan yang ada di masyarakat yang perlu mendapatkan perhatian khusus yaitu masalah poligami.

Poligami sebagaimana kita ketahui merupakan hal yang sudah sangat sering dibicarakan. Akan tetapi solusi yang ditawarkan kebanyakan masih bertendensi dengan kepentingankepentingan yang fiktif. Akibatnya timbul perdebatan yang tak ada ujung penyelesaiaanya. Oleh karena itulah pada kesempatan ini saya akan mencoba menawarkan status poligami yang sebenarnya dengan mempertimbangkan undang-undang keluarga Islam Indonesia, undang-undang negara muslim yang lain, tinjauan fiqih, dan berusaha mengkontekstualkan kembali poligami. Hal ini sebagai langkah awal untuk menemukan kembali posisi poligami yang ideal dalam kajian keislaman.

\section{KONSEP POLIGAMI DALAM PERUNDANG-UNDANGAN INDONESIA}

Indonesia sebagai Negara hukum membahas masalah poligami dengan pembahasan yang sangat terperinci. Terlihat jelas kurang lebih ada 5 pedoman sebagai peraturan tentang poligami yaitu UU No. 1 Tahun 1974, PP No. 9 Tahun 1975, PP No. 10 Tahun 1983, PP No. 45 Tahun 1990, dan Kompilasi Hukum Islam (KHI).

Berdasarkan UU No. 1 tahun 1974 yang menyatakan bahwa system kekeluargaan yang dianut oleh Negara Indonesia adalah 
pernikahan yang monogini/monogami. ${ }^{1}$ Dalam undang-undang ini meskipun pada prinsipnya seseorang itu harus bermonogami/ monogini akan tetapi pada penjelasan berikutnya memperbolehkan seseorang untuk berpoligami yaitu dengan ketentuan bahwa pengadilan dapat memberikan izin kepada suami untuk berpoligami dengan persetujuan pihak yang terkait ${ }^{2}$. Kaitannya dengan hal ini suami apabila menginginkan untuk berpoligami harus mengajukan permohonan kepada pengadilan setempat. ${ }^{3} \quad$ Dalam hal ini pengadilan terlebih dahulu mempertimbangkan kondisi si isteri dalam hal moralitas dan kondisi kesehatan khususnya reproduksi. Setelah semua hal tersebut telah terpenuhi harus ada peresetujuan dari pihak-pihak yang bersangkutan bisa jadi persetujuan tersebut lisan atau tertulis yang penting disampaikan di muka pengadilan ${ }^{4}$ dan jaminan kesejahteraan financial yang dibuktikan dengan penghasilan, pajak penghasilan, dan keterangan lain yang dibutuhkan pengadilan dari suami. ${ }^{5}$ Selain itu ada persyaratan yang pokok yang harus dipenuhi oleh seorang suami yaitu kebolehan poligami itu maksimal 4 orang dan suami mampu untuk berlaku adil. Jika syarat tersebut tidak terpenuhi maka suami dilarang untuk melakukan poligami. ${ }^{6}$

Berbeda lagi jika yang mengajukan poligami adalah seorang PNS (Pegawai Negeri Sipil). Peraturan pemerintah dalam hal ini

\footnotetext{
${ }^{1}$ UU No. 1 tahun 1974 pasal 3 ayat 1 yang menyatakan bahwa "Pada asasnya seorang pria hanya boleh memiliki seorang isteri. Seorang wanita hanya boleh memiliki seorang suami".

${ }^{2}$ UU No. 1 tahun 1974 pasal 3 ayat 2 yang menyatakan bahwa "Pengadilan, dapat memberi izin kepada seorang suami untuk beristeri lebih dari seorang apabila dikendaki oleh pihak-pihak yang bersangkutan."

${ }^{3}$ Cara pengajuan ke pengadilan harus disampaikan secara tertulis. Kemudian dari pernyataan pengajuan tersebut pengadilan mempertimbangkan ada atau tidaknya alas an yang memunkinkan suami kawin lagi, sebagaimana yang terncantum pada pasal 4 ayat 2 UU No. 1 tahun 1974.

${ }^{4}$ PP No. 9 tahun 1975 pasal 41

${ }^{5}$ Lihat: UU No. 1 tahun 1974 pasal 4 dan 5

${ }^{6} \mathrm{KHI}$ pasal 55 ayat 1,2 , dan 3 .
} 
lebih ketat lagi. Selain seorang suami itu telah memenuhi persyaratan yang ada dalam UU No. 1 tahun 1974, PP No. 9 tahun 1975, dan Kompilasi Hukum Islam (KHI), ada ketentuan special yang diatur dalam PP No. 10 tahun 1983 dan PP No. 45 tahun 1990.

Untuk Pegawai Negeri Sipil yang menginginkan beristeri lebih dari satu maka harus mendapat izin dari pejabat. Untuk pegawai negeri sipil wanita tidak diizinkan menjadi isteri kedua/ketiga/keempat. Selain nantinya mengajukan ke pengadilan, suami harus terlebih dahulu mengajukan secara tertulis kepada pejabat disertai dengan alasan yang lengkap. ${ }^{7}$ Jika pada kenyataannya pegawai negeri sipil melangsungkan poligami tanpa ada kesepakatan dari pejabat akan mendapat 4 kemungkinan hukuman, bisa jadi penurunan pangkat setingkat lebih rendah, pembebasan jabatan, pemberhentian dengan hormat atas permintaan sendiri, dan pemberhentian dengan tidak hormat sebagai PNS. $^{8}$

Berdasarkan UU No.1 tahun 1974 jelas menyatakan bahwa walaupun secara tertulis memberikan titik terang bagi pelaku poligami akan tetapi sebenarnya undang-undang ini menekankan untuk lebih memilih untuk bermonogami. Hal ini terlihat jelas bagaimana syarat-syarat yang harus dipenuhi. Meskipun pertimbangan kondisi dari seorang isteri dinilai sangat rentan untuk tidak bahagia, lebih disebabkan karena ketidak berdayaan yang menjadi suratan takdir. Akan tetapi undang-undang lebih mendahulukan perasaan seorang isteri dari pada izin poligami. Seandainya ada izin dari isteri/isteri-isteri hal itu merupakan cerminan dari kewibawahan isteri/isteri-isteri. Betapa sangat lapang dada seorang isteri yang pada saat suaminya mengajukan izin kepadanya untuk berpoligami ia berada dalam suatu kondisi yang sangat membutuhkan perhatian dan dukungan. Suatu hal yang sebenarnya sulit diterima oleh naluri perasaan pada saat

${ }^{7}$ Lihat PP Nomor 10 Tahun 1983 pasal 4

${ }^{8}$ PP No. 30 tahun 1980 pasal 6 ayat 4 
sang isteri didera beban yang sangat menghentakkan jiwa, si suami menginginkan untuk membagi cintanya kepada yang lain. Sungguh suatu hal yang meluruhkan kesakinahan, kemawadahan, dan kewarahmahan.

Begitu juga di dalam KHI menyantumkan bahwa pihak pengadilan memberikan ketentuan yang sangat ketat bagi suami yang menginginkan poligami. Pertimbangan pengadilan tidak hanya masalah materi yang dinilai cukup untuk beristeri lebih dari satu melainkan ada pertimbangan yang mendasar yaitu kemampuan suami untuk berlaku adil. Untuk itulah masalah poligami jelas yang menjadi kebijakan adalah para hakim di pengadilan agama. Sebisa mungkin kebijakan yang diterapkan mampu menjaga hak dan kewajiban suami dan isteri. Lebih khusus lagi mampu menjaga perasaan isteri yang kebanyakan serba "pasrah" dari apa yang sedang dihadapi.

\section{KONSEP POLIGAMI DALAM PERUNDANG-UNDANGAN NEGARA- NEGARA MUSLIM}

\section{Undang-undang Negara Malaysia}

Malaysia sebagai Negara yang mayoritas penduduknya muslim terbesar setelah Indonesia dalam perundanngundangannya juga mengatur masalah poligami. Pedoman pokok dinegara tersebut adalah seksyes 23 akta undang-undang keluarga Islam (AUKI) (wilayah-wilayah perekutuan) 1984. Wilayah persekutuan tersebut menyangkut Serawak, Kelatan, Perak, Pinang, Selangor, johor, Pahang, perlis, sabah, trengganu, malaka, kedah dan Negeri Sembilan. ${ }^{9}$ Dalam AUKI 1984 poligami merupakan hal yang keberadaannya itu dipersyaratkan. Pada saat seseorang mengajukan izin poligami ke mahkamah, dikabulkan

${ }^{9}$ Tahir Mahmud, Family Law Reform in the Muslim World, (New Delhi: N.M. TRIPATHI PVT. LTD, 1974), h. 199 
atau tidaknya permohonan izin tersebut mahkamah mempertimbangkan 4 hal yaitu ${ }^{10}$ :

- Perkawinan yang dicadangkan itu adalah patut dan perlu memandang kepada isteri dari segi kemandulan, keuzuran jasmani, tidak layak dari segi jasmani untuk persetubuhan, sengaja ingkar mematuhi untuk pemulihan hak-hak persetubuhan, atau gila. ${ }^{11}$

- Pemohon mempunyai kemampuan mengikuti kehendak syara' untuk menanggung semua isteri dan tanggungannya termasuk orang yang bakal ditanggungnya berikutan dari perkawinan yang baru.

- Pemohon berupaya memberi layanan sama rata kepada semua isteri mengikut kehendak hukum syara'. ${ }^{12}$

- Perkawinan yang dicadangkan tidak menyebabkan darar syar'i kepada isteri. ${ }^{13}$

Berdasarkan pertimbangan di atas, nampaknya mahkamah (pengadilan) malaysia lebih menekankan pada keadaan fisik seorang isteri terbukti persyaratan yang utama adalah kondisi jasmani isteri. Pengadilan mempertimbangkan kondisi pemohon dengan mengacu bagaimana ketentuan syara' itu bisa terpenuhi, baik itu urusan lahir maupun batin. Pertimbangan lain yang lebih penting adalah pemohon mampu untuk memberikan kemashlahatan dengan adanya poligami tersebut, tidak menimbulkan kerugian bagi pihak-pihak yang terkait.

${ }^{10}$ Seksyes 23 (4) Akta Undang-Undang Keluarga Islam (AUKI) (WilayahWilayah Perekutuan) 1984

${ }^{11}$ Hal ini juga sesuai dengan ketentuan UU Serawak 21 (3) a, UU Pahang 23 (4) a, UU Negeri Sembilan 23 (4) a.

${ }^{12}$ Hal ini juga sesuai dengan ketentuan UU Serawak 21 (3) b dan c, UU Pahang 23 (4) b dan c, UU Negeri Sembilan 23 (4) b dan c, UU Selangor 23 (4) b dan c, UU Pinang 23 (4) b dan c.

${ }^{13}$ Hal ini juga sesuai dengan ketentuan UU Serawak 21 (4) d dan e, UU Pahang 23 (4) d dan e, UU Negeri Sembilan 23 (4) d dan e, UU Selangor 23 (4) d dan e, UU Pinang 23 (4) d dan e. 
Jika pada kenyataannya suami tidak memenuhi persyaratan di atas pengadilan berhak untuk tidak mengabulkan permohonan poligami. Jika pemohon membulatkan tekat untuk berpoligami meskipun tanpa ada persetujuan dari pengadilan maka pengadilan berhak menghukum yang bersangkutan dengan denda tidak melebihi satu ribu ringgit atau penjara tidak lebih dari enam bulan bahkan bisa jadi dihukum kedua-duanya. ${ }^{14}$

Menjadi jelas bagaimana Malaysian mengatur masalah poligami secara ketat, walaupun lebih ketat Indonesia, akan tetapi Malaysia berupaya bahwa poligami itu merupakan solusi yang ditawarkan sebagai jalan akhir untuk menuju keluarga yang sakinah, mawaddah, dan rahmah. Persyaratan kemampuan lahir dan adil adalah cerminan bahwa poligami merupakan upaya untuk menjaga martabat perempuan. Perempuan dalam tinjauan poligami di Malaysia bukan sebagai pemuas sex belaka melainkan pihak yang sangat menentukan untuk terciptanya keluarga yang ideal.

\section{Ketentuan poligami di Brunei Darussalam}

Sebagaimana Negara-negara lain brunei Darussalam juga mengatur masalah poligami agar tidak dilakukan secara liar. Campur tangan pemerintah (hakim) sebagai tolok ukur kemapuan seseorang untuk berpoligami. Hal ini sebagai upaya untuk melindungi hak-hak isteri dan anak-anak.

Menurut Khairuddin Nasution yang mengutip dari Anderson yang menyatakan bahwa hukum administrasi muslim tahun 1968 (the administration of muslim law act of 1968) menetapkan bahwa seorang suami yang sudah beristeri tidak boleh melakukan perkawinan kecuali ada putusan hakim (kathi) ${ }^{15}$

${ }^{14}$ UU Pinang pasal 123, UU Selangor pasal 123, UU negeri Sembilan pasal 123, UU Pahang pasal 124, UU perak pasal 118, UU Serawak pasal 125.

${ }^{15}$ Khairuddin Nasution, Hukum Perdata (Keluarga) Islam Indonesia dan Perbandingan Hukum Perkawinan di Dunia Muslim (Studi Sejarah, Metode Pembaharuan, dan Materi) dan Status Perempuan Dalam Perundang-Undangan 


$$
\begin{aligned}
& \text { - } \quad \text { Undang-udang Filiphina }{ }^{16} \\
& \text { - } \quad \text { Undang-undang Turki. }{ }^{17} \\
& \text { - } \quad \text { Undang-undang mesir. }{ }^{18} \\
& \text { - } \\
& \text { Undang-undang Iran. }{ }^{19}
\end{aligned}
$$

Perkawinan Muslim, (Cet. ke-1; Yogyakarta: ACAdeMA dan TAZZAFA, 2009), hal. 283.

${ }^{16}$ Dalam UU keluarga Philippines (code of muslim personal law of the philippines) no. 1083 tahu 1977 ditetapkan, meskipun poligami diperbolehkan sampai empat orang isteri, tetapi pembolehan tersebut adalah tindakan pengecualian, dengan syarat dapat berbuat adil di antara isteri-isterinya. Ibid.

${ }^{17}$ Undang-undang yang digunakan di turki adalah UU Civil Turki Tahun 1926 (the Turkish civil code 1926). Suami yang akan berpoligami harus mampu untuk berlaku adil kepada para isterinya. Akan tetapi tidak serta merta poligami dibolehkan melainkan isteri berhak mengajukan ta'lik talak pada saat akad nikah bahwa suami tidak boleh menikah lagi. Dalam artian ketika suami berpoligami isteri berhak mengajukan cerai. Akan tetapi turki sudah menghapus praktek poligami dengan pedoman poligami dalam Islam sangat berat karena berlaku adil kepada para isteri merupakan hal yang sulit. Sehingga turki secara resmi menghapus praktek poligami. http://wikiberita.net/poligami-di-turki-dan-tunisia-sudah-dihilangkan.html

${ }^{18}$ Aturan poligami di mesir di atur dalam UU (Amandement law) no. 100 tahun 1985. Di dalam undang-undang ini seorang yang berpoligami harus mampu berbuat adil dan mampu secara materi. Untuk pihak isteri poligami bisa menjadi alas an perceraian bagi si isteri karena poligami mengakibatkan kesenjangan ekonomi. Pengajuan perceraian tersebut bisa berupa ta'lik talak atau tidak Khairuddin, Ibid, hal. 286. Dengan ketentuan mampu dalam segi materi maka di mesir poligami menjadi fenomena yang terus menuai kontrofersi, karena hanya orang-orang kaya yang mampu untuk berpoligami. Menikah sendiri menjadi suatu yang mahal dan susah. Sementara jumlah lakilaki berbanding terbalik, lelaki lebih banyak setengahnya dari jumlah perempuan. http://indonesia.faithfreedom.org/forum/dosen-al-azhar-mesirada-poligami-bukan-ajaran-Islam-t31730/

${ }^{19}$ Berdasarkan Family Protection Act of 1967 yang kemudian diperbaharui pada tahun 1975. Pada intinya Iran sangat melindungi hak-hak isteri terbukti dalam aturannya suami yang akan berpoligami harus mampu dalam segi ekonomi dan adil. Peran isteri dalam hal ini sebagai pihak pemberi izin atas poligami suami. Jika suami tanpa izin isteri berpoligami maka isteri bisa mengajukan cerai.

Dalam hal ini pengadilan sebagai pihak yang melegalkan polgami tersebut harus benar-benar berperan andil dalam hal poligami. Keandilan tersebut berdampak ketika suami tidak mendapat izin melakukan poligami 
Baru-baru ini di Iran timbul pententangan dari pihak perempuan tentang pembolehan poligami. Mereka beralasan bahwa poligami akan melemahkan peran dan status mereka dalam berumah tangga dan dalam masyarakat. Aliansi-aliansi dan organisasi-organisasi Islam seperti Zeinab association dan Women's Organisation of the Islamic Revolution juga mendukung gerakan ini. $^{20}$

- Undang-undang Banglades dan Pakistan. ${ }^{21}$

- Undang-undang Tunisia. ${ }^{22}$

- Undang-undang Yordania. ${ }^{23}$

- Undang-undang Maroko. ${ }^{24}$

- Undang-undang Irak. ${ }^{25}$

maka pengadilan bisa menjatuhkan hukuman selama 2 tahun Khairuddin, Ibid, h. 288

${ }^{20}$ http://gagasanhukum.wordpress.com/2010/03/22/perempuan-iranmenentang-poligami/

${ }^{21}$ Dengan the muslim family laws ordinance tahun 1961 menetapkan kebolehan poligami dengan izim lebih dahulu dari pengadilan (arbitration council). Sementara yang melanggar peraturan ini dapat dihukum dengan hukuman penjara atau denda.Khairuddin Nasution, Ibid., h. 288

${ }^{22}$ Dengan UU Keluarga (code of personal status/majallat al-ahwal alshakhsiyah no.66 tahun 1956) melarang poligami secara mutlak, dengan alas an pertama, intitusi budak dan poligami hanya boleh pada masa perkembangan, tetapi dilarang setelah menjadi masyarakat yang berbudaya. Kedua, Q.S. alNisā' (4): 3 yang menetapkan bahwa syarat poligami harus mampu berlaku adil itu hanya rosul yang bisa berlaku adil. Ibid., h. 290

${ }^{23}$ Dengan undang-undang keluarga tahun 1951 yang diperbaharui dengan UU yordania tahun 1976 menetapkan, isteri berhak memasukkan dalam ta'lik talak, bahwa poligami suami dapat menjadikan alas an cerai bagi suami, dengan syarat harus dicatatkan dalam akad nikah. Ibid., h. 291

${ }^{24}$ Dengan undang-undang tahun 1958 menetapkan, isteri berhak memasukkan dalam ta'lik talak hak cerai isteri kalau suami melakukan poligami. Bahkan sekalipun isteri tidak mencantumkanhak tersebut dalam ta'lik talak, hakim dapat memberikan pertimbangan apakah perkawinan tersebut mengandung kemudharatan kepada isteri, dan kalau ada kekawatiran suami tidak mampu berlaku adil terhadap isteri-isterinya, poligami tidak diperbolehkan. Ibid., h. 292

${ }^{25}$ Dengan UU tahun 1959 menetapkan:(1) bahwa untuk poligami harus ada izin dari hakim, sementara poligami tanpa izin dari hakim maka tidak sah, dan (2) bahwa poligami menjadi alas an perceraian isteri. Poligami harus 


$$
\begin{aligned}
& \text { - Undang-undang Syiria. }{ }^{26} \\
& \text { - Undang-undang Somalia. }{ }^{27} \\
& \text { - Undang Aljazair. }{ }^{28} \\
& \text { - Undang-undang Libya. }{ }^{29}
\end{aligned}
$$

\section{POLIGAMI DALAM TELAAH FIQIH}

Poligami (ta'addudu al-jauzah) dalam kitab-kitab fiqih klasik lebih mengacu kepada status seseorang. Orang laki-laki yang merdeka (hurrun) boleh menikahi 4 orang perempuan, sedangkan budak laki-laki (abdun) hanya boleh menikahi 2 orang perempuan. ${ }^{30}$ Merdeka dan budak menjadi hal yang berpengaruh bagi keputusan hukum yang akan dibebankan. Terlepas dari hal itu posisi poligami memang tidak hanya kesanggupan dari segi

didukung dengan kemampuan si suami dan adanya unsure mashlahatnya. Dalam perundang-undangn irak khusus bagi janda boleh berpoligami tanpa mengikuti aturan yang berlaku. Ibid., h. 293-294

${ }^{26}$ Dengan personal status (qanun al-ahwal al-shakhsiyah al-suriyah), no. 59 tahun 1953, yang diperbaharui tahun 1975, termasuk undang-undang keluarga terdahulu yang membatasi kemungkinan poligami. Menurut undangundang no.34 tahun 1975 hanya hakim yang menentukan dapat atau tidaknya seorang berpoligami, yang ditentukan oleh ada atau tidaknya alas an hukum, kemampuan ekonomi suami, dan kemampuan suami berlkau adil. Isteri juga boleh mengajuka ta'lik talak sepanjang tidak memberatkan suami dalam hal pemenuhak hak dan kewajibanya. Sehingga poligami di syiria menjadi masalah jika mendapatkan keberatan dari pihak isteri. Namu jika ada yang melanggar akan dikenai hukuman sesuai hukum yang ada di syiria. Ibid., h. 294-296

${ }^{27}$ Undang-undang Somalia menetapkan, poligami hanya dapat dilakukan dengan izin pengadilan, karena ada alas an hukum, yakni isteri mandul dengan bukti surat keterangan dokter, isteri dipenjara lebih dari dua tahun, isteri meninggalkan rumah tanpa izin, dan ada kebutuhan sosial Ibid., h. 296

${ }^{28}$ Aljazair memperbolehkan poligami maksimal 4 isteri dengan syarat ada alas an hukum. Namun poligami dapat menjadi alas an perceraian bagi isteri, kalau dilakukan tanpa sepengetahuannya Ibid, hal. 296

${ }^{29}$ Libya memperbolehkan poligami, dengan syarat lebih dahulu mendapat izin dari pengadilan. Untuk memberikan izin atau tidak, pengadilan mempertimbangkan kondisi sosial, kemampuan ekonomi,, dan fisik laki-laki yang memohon. Ibid., h. 297

${ }^{30}$ Ibnu Qasim al-Ghazi, Fath al-Qarīb al-Mujīb, (t.tp.: al-Maktabah alSyamilah, t.th), h. 112 
fisik dan batin saja, melainkan kemampuan harta juga sangat diperhatikan. Inilah pertimbangan yang pantas ketika memilah antara yang merdeka dan budak.

Ketentuan maksimal 4 itu merupakan harga mati, artinya seseorang yang sudah beristeri 4 kemudian ia ingin menikah untuk isteri yang ke 5 ia harus menceraikan salah satu dari ke 4 isterinya, setelah itu ia bisa memilih yang ia kehendaki. ${ }^{31}$ ada dua pendapat tentang batasan maksimal berpoligami, jumhur ulama menyimpulkan bahwa lafadz matsna wa tsulatsa wa ruba' mengindikasikan bahwa wawu ataf itu berfungsi sebagai li altakhyir bukan li al-jam'I, berbeda dengan kalangan mazhab dhahiriyyah dan syi'ah imamiyyah menyimpulkan bahwa wawunya berfungsi sebagai li al-jam'I sehingga batas maksimal untuk berpoligami adalah 9 .

Wahbah al-Zuhaily lebih menguatkan kepada pendapat yang menyatakan bahwa maksimal isteri itu 4. Beliau beralasan bahwa 1 bulan ada 4 minggu menjadikan kemudahan bagi lakilaki untuk membagi waktu bersama isteri-isterinya, pencurahan cinta dan kasih sayang akan lebih mudah dicurahkan kepada isteri-isterinya dalam batas waktu tidak melebihi satu bulan. Untuk beristeri lebih dari 4 itu ditakutkan berbuat aniaya dan lemah dalam memenihi hak-hak para isteri. Hal inilah yang mengindikasikan bahwa laki-laki yang takut untuk tidak berlaku adil maka baginya lebih baik menikah dengan seorang saja. Keadilan ini menyangkut pembagian waktu, jima', dan nafaqah. Pendapat maksimal 4 ini bukan berarti laki-laki boleh menikah lebih dari 1, hal ini hanyalah merupakan pengecualian yang jarang sekali, bahkan beristeri satu it merupakan hal yang umum dan paling utama. ${ }^{32}$

\footnotetext{
${ }^{31}$ Wahbah al-Zuhaily, al-Fiqh al-Islām wa Adillatuh, juz 7 (Demaskus: Dār al-Fiqr, 1985), h. 165

${ }^{32}$ Ibid., h. 167
} 
Tinjauan lain yang menyimpulakn bahwa poligami itu bisa sunnah, makruh, dan haram adalah ${ }^{33}$ :

- Sunnah ketika ada kerelaan dari isteri pertama, atau isteri yang pertama dalam keadaan sakit yang tidak memungkinkan untuk mempunyai anak, di satu sisi suami sangat mendambakan anak dan dia yakin mampu untuk berbuat adil. Hal inilah menjadikan poligami itu disunahkan karena adanya kemashlahatan yang disyari'atkan. Hal ini juga dilakukan oleh mayoritas para shahabat.

- Makruh ketika dia berpoligami tanpa ada kebutuhan, hanya untuk kenikmatan dan bersenang-senang disertai dengan keragu-raguan untuk berlaku adil kepada para isterinya.

- Haram ketika dia yakin bahwa dia tidak bisa berlaku adil, adakalanya karena kemiskinan, kelemahan atau tidak adanya gairah untuk membagi perhatian kepada para isteri.

Sesuai dengan hal di atas bahwa hukum poligami yang ditawarkan Islam berubah sesuai dengan kondisi yang terpenuhinya menjadi perantara untuk mencapai tujuan pokok pernikahan yaitu sakinah, mawaddah, wa rahmah.

Kemudian secara umum, di dalam fiqih ada 2 syarat yang harus dipenuhi oleh seorang suami yang akan melakukan poligami yaitu adil dan mampun dari segi materi.

Adil dalam masalah poligami diartikan sebagai kemapuan seseorang untuk menyamaratakan kepada para isteri nafaqah, kebagusan berkumpul, dan menginap. ${ }^{34}$ Untuk masalah adil ini tidak hanya menjadi syarat mutlak melainkan juga sebagai batasan seorang yang baginya cukup beristeri satu saja jika takut

\footnotetext{
${ }^{33}$ Mustafa Khan, Mustafa al-Bighā dan Ali al-Syarbaji, Al-Fiqh alManhajiy 'alā Mażhab al-Imām al-Syafi'ī, Juz 1 (al-Maktabah al-Syamilah, t.th.), h. 409

${ }^{34}$ Wahbah al-Zuhaily, al-Fiqh al-Islām .., Juz 7, h. 168, dan juga Al-Syafi'ī, al-Umm, Juz 5, (al-Maktabah al-Syamilah, t.th.), h. 204
} 
tidak mampu berlaku adil. Cakupan adil bukan pada kasih sayang, cinta, dan kecenderungan hati. Karena hal tersebut tidak ada seorang yang mampu dan sulit diukur.

Mampu dalam hal nafaqah merupakan syarat lain yang harus terpenuhi. Karena hal yang paling berpengaruh dalam berkeluarga adalah sebagaimana seorang suami mampu mencukupi kebutuhan materi keluarga. ${ }^{35}$

Patut untuk digaris bawahi bahwasannya poligami dalam tinjauan fiqih merupakan suatu perintah yang dikecualikan dan jarang terjadi. Keberadaannya karena adanya hajat yang fundamental. Sehingga fiqih tidak mewajibkan seseorang untuk berpoligami, bahkan fiqih tidak menghendaki seseorang untuk berpoligami.

Terealisasinya poligami dalam konsep fiqih hanya berpacu pada sebab umum dan khusus. Adapun sebab umum itu dikarenakan jumlah laki-laki lebih sedikit dari pada wanita dengan berbagai sebab, bisa jadi karena bencana, peperangan, atau fenomena angka kelahiran yang kebanyakan anak perempuan. Semua itu tidak menjadikan penghalang untuk meneruskan syi'ar agama Islam, dalam konteks seperti inilah poligami menuai kemudahan. Adapun sebab khusus hanya menyangkut pada kondisi-kondisi tertentu yang dapat mengurangi kebahagiaan, seperti ketidak hadiran anak, sakitnya

${ }^{35}$ Wahbah al-Zuhaily, Ibid. materi dalam berkeluarga juga menjadi pertimbangan penting bagi seseorang yang berniat untuk menikah sebagai mana hadits nabi:

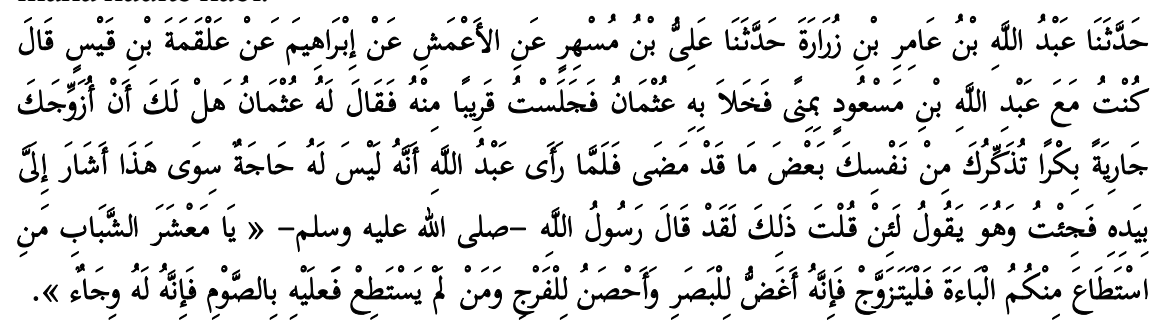
Abu Ab́dillah Muhammad ibn Yazid al-Quzwainy, Sunan Ibnu Majjah, Juz: 6, (alMaktabah al-Syamilah, t.th.), h. 19 
isteri, atau sangkin begitu nafsunya seorang laki-laki yang menyebabkan satu isteri tidak mampu melayani secara biologis. Secara garis besar dibolehkannya poligami hanya dibatasi ketika dharurat, kebutuhan, uzhur, dan timbulnya mashlahat. ${ }^{36}$

Pada era kontemporer perlu adanya pengkajian langsung tentang permasalahan poligami dari at-Tanzil al-Hakim. Menarik untuk dicermati bahwa dalam surat al-Nisā' ayat 1-6 menberikan sistematika pemahaman yang untuk terkait dengan poligami. Dalam surat tersebut Allah menegaskan kembali tentang isi pokok pada akhir surat Ali Imrān ${ }^{37}$ tentang seruan kepada Allah, seruan untuk menyambung tali silaturahmi dengan berpangkal dengan berpangkal pada keuniversalan manusia, bukan pada kelompok atau kesukuan yang sempit, sebagai penegasan bahwa manusia itu tercipta dari nafs yang sama (nafs wahidah). ${ }^{38}$

Pada ayat yang selanjutnya yaitu ayat 2 dan 3 Allah kemudian memberikan penjelasan tentang anak yatim. Pada ayat yang ke 2 Allah memerintahkan untuk memberikan hak-hak anak yatim yang berupa harta peninggalan dan tidak memakannya. ${ }^{39}$

${ }^{36}$ Wahbah al-Zuhaily, Ibid., h. 171

${ }^{37}$ Dan Sesungguhnya diantara ahli kitab ada orang yang beriman kepada Allah dan kepada apa yang diturunkan kepada kamu dan yang diturunkan kepada mereka sedang mereka berendah hati kepada Allah dan mereka tidak menukarkan ayat-ayat Allah dengan harga yang sedikit. mereka memperoleh pahala di sisi Tuhannya. Sesungguhnya Allah Amat cepat perhitungan-Nya. Hai orang-orang yang beriman, bersabarlah kamu dan kuatkanlah kesabaranmu dan tetaplah bersiap siaga (di perbatasan negerimu) dan bertakwalah kepada Allah, supaya kamu beruntung.

${ }^{38} \mathrm{Hai}$ sekalian manusia, bertakwalah kepada Tuhan-mu yang telah menciptakan kamu dari seorang diri, dan dari padanya Allah menciptakan isterinya; dan dari pada keduanya Allah memperkembang biakkan laki-laki dan perempuan yang banyak. dan bertakwalah kepada Allah yang dengan (mempergunakan) nama-Nya kamu saling meminta satu sama lain, dan (peliharalah) hubungan silaturrahim. Sesungguhnya Allah selalu menjaga dan mengawasi kamu.

${ }^{39}$ Dan berikanlah kepada anak-anak yatim (yang sudah balig) harta mereka, jangan kamu menukar yang baik dengan yang buruk dan jangan kamu 
Kemudian pada ayat yang ke-3 Allah menindaklanjuti pembahasan tentang anak-anak yatim dengan perintah kepada manusia untuk menikahi perempuan-perempuan yang disenangi: 2, 3, atau 4, yang dibatasi pada kondisi yaitu takut tidak dapat berlaku adil kepada anak-anak yatim. ${ }^{40}$ Kemudian pada ayat yang ke empat ${ }^{41}$, Allah SWT melanjutkan pembahasan tentang maskawin dan mahar bagi perempuan, dan pada ayat yang kelima $^{42}$ tentang larangan kepada manusia untuk menyerahkan kepada orang-orang yang belum sempurna akalnya harta benda mereka, kemudian Allah mempertegas lagi tentang pembahasan anak yatim pada ayat yang ke-6. ${ }^{43}$

Muhammad Syahrur memberikan penjelasan tentang anak yatim yang dimaksudkan pada surat an-nisa'. Kata al-yatīm dalam

Makan harta mereka bersama hartamu. Sesungguhnya tindakan-tindakan (menukar dan memakan) itu, adalah dosa yang besar.

${ }^{40}$ Dan jika kamu takut tidak akan dapat Berlaku adil terhadap (hak-hak) perempuan yang yatim (bilamana kamu mengawininya), Maka kawinilah wanitawanita (lain) yang kamu senangi : dua, tiga atau empat. kemudian jika kamu takut tidak akan dapat Berlaku adil, Maka (kawinilah) seorang saja, atau budakbudak yang kamu miliki. yang demikian itu adalah lebih dekat kepada tidak berbuat aniaya.

${ }^{41}$ Berikanlah maskawin (mahar) kepada wanita (yang kamu nikahi) sebagai pemberian dengan penuh kerelaan. kemudian jika mereka menyerahkan kepada kamu sebagian dari maskawin itu dengan senang hati, Maka makanlah (ambillah) pemberian itu (sebagai makanan) yang sedap lagi baik akibatnya.

${ }^{42}$ Dan janganlah kamu serahkan kepada orang-orang yang belum sempurna akalnya, harta (mereka yang ada dalam kekuasaanmu) yang dijadikan Allah sebagai pokok kehidupan. berilah mereka belanja dan pakaian (dari hasil harta itu) dan ucapkanlah kepada mereka kata-kata yang baik.

${ }^{43}$ Dan ujilah anak yatim itu sampai mereka cukup umur untuk kawin. kemudian jika menurut pendapatmu mereka telah cerdas (pandai memelihara harta), Maka serahkanlah kepada mereka harta-hartanya. dan janganlah kamu Makan harta anak yatim lebih dari batas kepatutan dan (janganlah kamu) tergesagesa (membelanjakannya) sebelum mereka dewasa. barang siapa (di antara pemelihara itu) mampu, Maka hendaklah ia menahan diri (dari memakan harta anak yatim itu) dan Barangsiapa yang miskin, Maka bolehlah ia Makan harta itu menurut yang patut. kemudian apabila kamu menyerahkan harta kepada mereka, Maka hendaklah kamu adakan saksi-saksi (tentang penyerahan itu) bagi mereka. dan cukuplah Allah sebagai Pengawas (atas persaksian itu). 
bahasa arab dan at-Tanzil al-Hakim berarti seorang anak yang belum mencapai umur balig yang telah kehilangan ayahnya, sementara ibunya masih hidup. ${ }^{44}$ Hal ini tidak lain merupakan penjelasan dari surat an-nisa': $6^{45}$, al-kahfi: $82^{46}$, dan al-an'am: 152. ${ }^{47}$ Sehingga jelas bahwa konteks anak yatim yang dimaksudkan pada ayat tersebut yaitu mereka yang ayahnya telah meninggal sementara ibu mereka masih hidup menjanda. Bukan kehilangan ibu atau kehilangan ibu dan bapak, karena hal tersebut akan menggugurkan kebolehan poligami.

Timbul suatu permasalahan ketika kita hendak berbuat baik dan adil kepada mereka, menjaga dan memelihara harta mereka ketika telah dinilai sudah dewasa. Bagaimana hal itu bisa terwujud pada saat mereka masih dalam asuhan ibunya, haruskah mereka dipisahkan dengan ibunya, atau membiarkan mereka mengurus sendiri kebutuhannya ? semua itu mungkin saja terjadi, akan tetapi ada kenyataan lain bahwa kita pada suatu saat tidak dapat melaksanakan perintah Allah dengan baik. Kekhawatiran ketidak mampuan untuk berlaku adil kepada anak-anak yatim membuahkan solusi ddiperbolehkannya poligami dengan

\footnotetext{
${ }^{44}$ Muhammad Syahrur, Nahw Ushūl Jadīdah li al-Fiqh al-Islāmī, Fiqh Mar'ah (Al-Wașiyyah, al-Irś, al-Qawāmah, al-Ta'addudiyyah, al-Libās), (Suriyah: Maktabah al-Asad, 2000), h. 302.

${ }^{45}$ Dan ujilah anak yatim itu sampai mereka cukup umur untuk kawin

${ }^{46}$ Adapun dinding rumah adalah kepunyaan dua orang anak yatim di kota itu, dan di bawahnya ada harta benda simpanan bagi mereka berdua, sedang Ayahnya adalah seorang yang saleh, Maka Tuhanmu menghendaki agar supaya mereka sampai kepada kedewasaannya dan mengeluarkan simpanannya itu, sebagai rahmat dari Tuhanmu; dan bukanlah aku melakukannya itu menurut kemauanku sendiri. demikian itu adalah tujuan perbuatan-perbuatan yang kamu tidak dapat sabar terhadapnya".

${ }^{47}$ Dan janganlah kamu dekati harta anak yatim, kecuali dengan cara yang lebih bermanfaat, hingga sampai ia dewasa. dan sempurnakanlah takaran dan timbangan dengan adil. Kami tidak memikulkan beban kepada sesorang melainkan sekedar kesanggupannya. dan apabila kamu berkata, Maka hendaklah kamu Berlaku adil, Kendatipun ia adalah kerabat(mu), dan penuhilah janji Allah. yang demikian itu diperintahkan Allah kepadamu agar kamu ingat.
} 
menikahi ibu-ibu mereka yang menjanda. Terkait dengan hal itu khitab yang ditujukan kepada mereka yang telah beristri bukan kepada para bujangan-bujangan yang mengawini janda yang mempunyai anak yatim. Ini dibuktikan dengan penegasan pengawalan dua dan diakhiri empat. Sehingga istri yang ke 2, 3, dan 4 adalah para janda dan harus disertai rasa kekhawatiran tidak mampu berlaku adil kepada anak-anak yatim. ${ }^{48}$ Para jandapun dalam hal ini mendapat keistimewaan yaitu mereka sangat dimuliakan, dijaga perasaannya, dan dihormati posisinya dalam masalah perkawinan. Hal ini terbukti dengan Allah menggunakan ungkapan yang halus yaitu ma thaba laku bukan fankihu ma syi'tum mina an-nisa'I (maka nikahila wanita-Wanita yang kamu kehendaki), karena antara kata thaba dan sya'a mengandung perbedaan yang sangat significant. Meskipun begitu kita harus menghindari rasa menggebu-gebu untuk mendapatkan keridlaan Allah dengan mengesampingkan kemampuan materi yang kita punyai. Inilah sebenarnya poligami berada pada konteks pemahaman sosial kemasyarakatan, bukan pada konteks biologis (seks), dan berkisar pada permasalahan anak-anak yatim serta berbuat adil kepada mereka. Meskpun terjadi menekanan, disatu sisi adanya penguatan bahwa menikahi hanya satu orang saja dapat menjauhkan dari belenggu kesulitan dan dari tindakan ketidak adilan. Keberangsungan poligami diharapkan dengan adanya seorang laki-laki disisi seorang janda akan mampu dan memeliharanya agar tidak terjatuh dari perbuatan keji, perlindungan kepada anak-anak yatim agar mereke tumbuh dan dididik secara baik, dan keberadaan sang ibu akan mendukung penjagaan dan pendidikan mereka.

Poligami dengan beracuan dengan konsepsi diatas akan memberikan pemahaman bahwa budaya partiarki yang telah tumbuh subur dalam kehidupan masyarakat dan kekuasaan seorang laki-laki bebas menawini 2, 3, atau 4 wajib dikritisi

\footnotetext{
${ }^{48}$ Muhammad Syahrur, Nahw..., h. 303
} 
dengan pertimbangan-pertimbangan di atas. Penggambaran yatama an-nisa' memberikan penegasan bahwa anak-anak yatim yang dimiliki oleh wanita-wanita (janda) kerena adanya hubungan mudlaf dan mudaf ilaih. at-Tanzil al-Hakim datang dengan membatasi poligami sampai 4 dan menetapkan persyaratan tertentu. Hal ini sebagai upaya membatu problem yang dihadapi oleh masyarakat, terkait kapan harus melaksanakan poligami dan kapan harus meninggalkannya. Ini sebagai penegas bahwa pendapat masyarakatlah yang menjadi acuan dalam penetapan status poligami dan hal ini terkait dengan berbagai negara yang menghukumi poligami. Ini sebagai penegas bahwa konteks haram maka polling masyarakat tidak menjadi acuan akan tetapi pada saat penghalalan makan polling dari masyarakat juga wajib dipertimbangkan. Untuk itu sesuatu yang diharamkan sudah pasti tidak ada tolenransi tapi untuk kehalalan bisa jadi akan dicegah (mamnu) dan pencegahannya itu tidak bersifat umum dan abadi. Oleh karena itulah poligami dalah sesuatu yang halal/dibolehkan, sehingga pada suatu waktu dia bisa jadi dicegah karena alasan tertentu dan ketika alasan itu sudah hilang makan pemberlakuan kebolehaanya harus tetap berjalan.

\section{POLIGAMI DALAM TELAAH HADIS-HADIS}

Beberapa riwayat hadis menyatakan bahwa Nabi Muhammad SAW memiliki beberapa istri, bahkan lebih dari empat, sebagaimana dalam riwayat Muslim yang menyatakan:

"Anas berkata: Nabi Muhammad SAW. Memiliki sembilan istri (H.R Muslim)

Hadis ini secara tersurat menyatakan bahwa istri nabi Muhammad SAW adalah sembilan. Dengan sumber dan informasi yang berbeda, disebutkan tentang nama-nama istri Nabi SAW:

Az-Zuhri menyatakan : istri-istri Nabi Muhammad adalah Khadijah binti Khuwailid dan Aisyah binti Abu Bakar da umi salamah binti Abu Umayyah dan Hafsah binti Umar dan Ummu 
Habibah binti al-Harist dan Zainab binti Jashy dan Saudah binti Zum'ah dan syafiyah binti Uyay. Sembilan istri selain hadijah adalah istri-istri Nabi yang tinggal dengan Nabi. Kemudian alKindiyyah dari keluarga Jun dan al-Aliyah binti Dhabyan dari keluarga Amir bin Kilab dan Zainab binti Khuzaimah dari keluarga Hilal. Nabi Muhammad tidak menikah lagi sampai khadijah wafat. Nabi memiliki dua hamab sahaya, Mariyah al-Qibtiyyah dan Raihanah binti Syam'un.

Dalam riwayat ini, secara rinci menyebutkan jumblah dan nama-nama para wanita yang pernah menjadi istri Nabi, yakni: (1) Khadijah binti Khuwailid, (2) Aisha binti Abu Bakar, (3) Ummu salama binti abu Juwairiya binti al-Harith, maimuna binti harist, dan sebagainya.

Tentang berapa jumblah wanita yang pernah dikawini Nabi SAW, memang terjadi perbedaan pendapat. Hal ini bisa di maklumi, mengingat wanita-wanita yang dikawini Nabi bukan hanya wanita-wanita meredeka Arab Quraisy (10 orang tersebut), tetapi juga para tawanan perang dan hamba sahaya (budak), terlepas dari beberpa jumblah istri Nabi tepatnya, yang pasti bahwa istri nabi lebih dari empat (batas maksimum untuk selain Nabi).

Mengapa Nabi berpoligami ? untuk menjawab pertanyaan tersebut, mengapa Nabi berpoligami, terlebih dulu kita melihat catatan perjalan pernikahan Nabi. Adalah tidak adil berbicara poligami Nabi, tanpa mengedepankan realitas perkawinan Nabi seutuhnya, dimana Nabi tidak berpoligami ketika menikah dengan Khadijah r.a. dalam awal dan sebagian besar waktu pernikahannya Nabi tidak poligami, sebagaimana dalam sebuah riwayat:

"Aisyah R.A berkata: Nabi tidak menikah lagi ketika bersama dengan Khadijah sampai Khadijah Wafat." 49

${ }^{49}$ Muslim, Șahih Muslim, 2: 371 
Adalah hal yang sangat menarik untuk dikedepankan bahwa pada saat beliau menjalani bahtera rumah tangga selama lebih kurang seperempat abad bersama Khadijah binti Khuwailid samapai khadijah wafat (620 M), Nabi tidak pernah menikahi wanita lain. Sungguh hal itu merupakan sesuatu yang sangat tidak laim oleh orang pada saat itu. Sebenarnya ada alasan-alasan yang bisa diterima akal-saat itu- kalau nabi berpoligami. Di antaranya adalah :

Pertama, Isti Nab jauh lebih tua, pada saat menikah usia Nabi 25 tahun dan jejaka, semetara Khadijah 40 Tahun dan janda dua kali. ${ }^{50}$ Sehingga dalam perkawinannya dengan khadijah (usia Khadijah 40-65 tahun), adalah wajar kalau kemudian Nabi berpoligami karena Nabi masih segar bugar, sementara Khadijah sudah mulai tua, ketika usia perkawinan menapaki belasan tahun (memasuki usia menupause).

Kedua, poligami merupakan tradisi yang dilakukan hampir semua orang saat itu.

Ketiga, Nabi adalah seorang bangsawan Quraisy, yang sudah barang tentu dianggap wajar bila Nabi melakuka sesuatu diluar batas kelaziman, apalagi terhadap sesuatu yang sudah lazim (poligami)

Keempat, Nabi tidak memiliki anak laki-laki yang hidup sampai besar, karean waktu itu memiliki anak perempuan dianggap belum memiliki anak sesungguhnya.

Dengan beberapa kekurangan diatas, sebenarnya bisa saja Nabi melakukan poligami, tetapi itu tidak dilakukan oleh Nabi. Bahkan Nabi baru melakukan poligami beberapa tahun ssetelah meninggalnya Khadijah, karena begitu besarnya kenangan Nabi

\footnotetext{
${ }^{50}$ Suami pertama Khadijah, Atiq bin Abd al Maknury meninggal dan menurunkan satu anak perempuan bernama Hindun.sedang suami kedua, Nabbas bin Zurrara at-Taimi juga meinggal dunia dengan memiliki dua keturunan (halal dan hindun) selengkapnya lihat, selengkapnya Departemen Agama, al-Quran dan sunnah, serta Undangan.
} 
pada Khadijah, bahkan sampai-sampai Aishah pun sering dibakar cemburu terhadap orang-orang yang sudah tiada, karena begitu seringnya Nabi menyebut-nyebut nama Khadijah, sebagaimana dalam sebuah riwayat.

"Aishah berkata, belum pernah aku cemburu terhadap istri-istri Nabi SAW. Sebgaimana cemburuku terhadap Khadijah, padahal beliau telah meninggal tiga tahun sebelum Nabi menikahiku. Karena Nabi SAW selalu menyebut-nyebut namanya dan Allah telah memerintahkan untuk memberi kabar gembira dengan rumah bambu di surgadan jika beliau menyembelih kambing, beliau memberikan juga untuk kawankawan Khadijah". ${ }^{51}$

Dengan melihat catatan diatas, maka ada beberapa hal yang perlu disoroti; pertama, perbandingan masa monogami dan masa poligamiNAbi adalah 25 tahun berbanding 8. Nabi bermonogami selama 25 tahun. Yakni sejak usia 25 tahun sampai Khadijah wafat (50 tahun). Nabi berpoligami (mulai tahun 2 dan $3 \mathrm{H}$ sampai Nabi wafar $10 \mathrm{H}$ ) kurang lebih selama 8 tahun dengan beberapa istri.

Kedua, ada alasan-alasan Rasional Nabi melakukan poligami pada saat bersama Khadijah, tetapi tidak dilakukan Nabi. Karena perkawinan Nabi dengan Khadijah adalah perkawinan yang sangat berkesan, terbukti Nabi sering menyebut dan memujinya di depan istri-istrinya yang lain, Nabi baru menikah lagi setelah beberapa tahun Khadijah meninggal dan Nabi sering enyambung silaturohmi dengan kerabat dan teman-teman Khadijah, meski Khadijah telah meninggal.

Ketiga, poligami Nabi dengan beberpa istri lebih didasari pertimbangan-pertimbangan tertentu, karena hampis semua istri Nabi yang dimadu dalam status janda, kecuali Aishah yang dinikahi Nabi masih sangat muda belia, yakni 6 tahun dan baru di kumpuli pada usia 9 tahun, sebagaiman dalam riwayat bukhari.

Poligami juga ada pada masa sahabat Nabi, taridi poligami yang sudah berlaku di Masyatakat Arab adalah tanpa batasan dan

\footnotetext{
${ }^{51}$ Muslim, Șahiḥ ..., 2;370.
} 
jumblah dan dengan tanpa syarat apapun. Dengan datangnya Islam poligami dibatasi 4 orang saja, sebagaimana kasus sahabat Ghailan bin Salamah al-Thaqafy yang emiliki sepuluh istri, oleh nabi disuruh memilih empat saja diantara mereka sebagi istrinya, sedangkan yang lain diceraikan.

Sejauh ini, penulis belum menemukan adanya hadist yang secara tegas seruan Nabi kepada para sahabat yang hanya beristri satu untuk berpoligami.seruan Nabi untuk menikah lebih bersifat anjuran kepada orang yang tidak dan belum menikah, untuk segera menikah. Tetapi ada kasus larangan atau dilarangnya Ali untuk memadu putri Rasullloh dengan wanita lain, karena mengandung dua Illah (alasan). Pertama, karena menyakiti fatimah yang juga berarti menyakiti Nabi dan yang kedua, khawatir adanya fitnah yang harus dihadapi Fatimah bila disatukan dengan putri musuh ayahnya, Juwairiyyah binti abu jahal. Dua alasan yang tersurat itulah yang dipegangi para Ulama untuk mengkhususkan larang poligami Nabi.

Dengan mencermati berbagai riwayat yang diatas, baik dalam riwayat Nabi berpoligami serta sahabat dan larangan Nabi terhadap Ali yang akan berpoligami.maka secara tektual adanya taarud atau kontradiksi. Ada beberap solusi alternatif menghadapi kontradiksi semacam itu. Yaitu dengan jalan mengkropomikan, yakin mencoba mengkompromikan dan mendialogkan dua hal tersebut agar diketemukan maksudnya. Adajuga yang menawarkan tarjiih, ada juga yang menawarkan konsep nasikh dan mansukh. Dan ada juga yang menawarkan untuk didiamkan saja.

Terlepas dari itu semua, penkaji hadis akan mencoba melakukan pendekatan dengan socio kutual yang berbeda dari para pengkajinya. Dan pengkaji mencoba mendialogkan hadist ini secara komprehensif.

Pertama, keberadaan poligami, jelas-jelas teks hadis yang ada-baik yang berkaiatan dengan praktek poligami Nabi maupun 
sahabat yang berpoligami-menjelaskan adanya aturan-aturan yang ketat yang harus dipenuhi, adanya batasan-batasan tertentu yang harus dipatuhi, baik dari segi jumblah maupun dari segi bagaimana kemudian menyikapi para istri itu. Aturan-aturan itulah yang membedakan poligami yang telah menjadi tradisi pada saat itu dengan tanpa batasan apapun baik dari segi jumblah maupun dari segi konsekuensi pasca menikah. Adanya pembatasn jumblah istri bagi para sahabat (maksimal 4).

Realitas sejarah menunjukan bahwa Nabi berpoligami bukan karena faktor reproduksi ataupun faktor lain. Karen Nabi menikahi dan memadu para janda yang membutuhkan perlindungan sosial dan bukan para gadis.kalau saja faktor libido sex yang menjadikan pertimbangan, Nabi tentunya akan menikahi para gadis jelita.

\section{USAHA MENGAKTUALISASIKAN POLIGAMI}

Sampai saat ini polemik poligami masih menjadi hal yang dipertentangkan oleh para intelektual muslim. Dengan memahami ayat yang sama hukum yang mereka cetuskan tidak jarang saling bertentangan. Salah satu pihak menyatakan bahwa poligami sudah tidak relevan lagi pada era sekarang, dengan dalih perempuan era sekarang tidak sama dengan perempuan pada waktu nabi menjelaskan poligami. Akan tetapi disatu sisi mereka yang mendukung menyatakan adanya poligami itu sebagai jalan keluar yang mungkin saja terjadi kaitannya dengan kondisi masyarakat.

Terlepas dari hal di atas, berikut ini akan dipaparkan nashnash yang menjelaskan poligami :

Umat Islam menyakini bahwa perintah poligami itu diterangkan oleh Allah SWT dalam al-qur'an surat an-nisa' ayat : 3 yang berbunyi : 


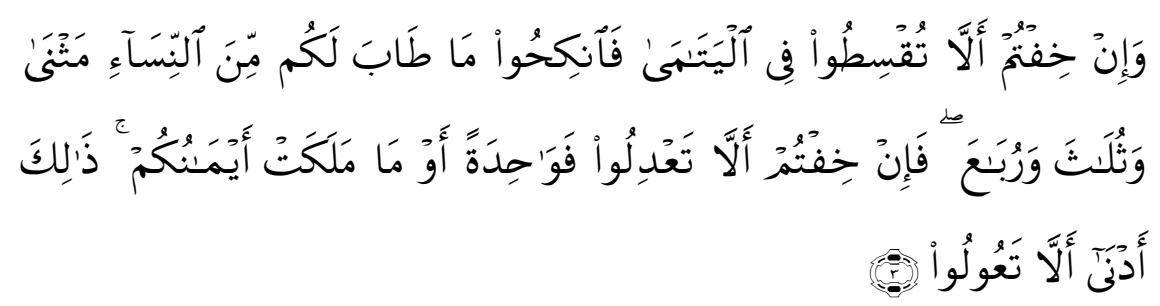

Artinya : Dan jika kamu takut tidak akan dapat Berlaku adil terhadap (hak-hak) perempuan yang yatim (bilamana kamu mengawininya), Maka kawinilah wanita-wanita (lain) yang kamu senangi : dua, tiga atau empat. kemudian jika kamu takut tidak akan dapat Berlaku adil, Maka (kawinilah) seorang saja, atau budak-budak yang kamu miliki. yang demikian itu adalah lebih dekat kepada tidak berbuat aniaya.

Jelas bahwa ayat ini menjelaskan tentang poligami memang keberadaannya diakui oleh Islam. Dari ayat di atas juga dijelaskan bahwa posisi poligami itu tidak terlepas dari dua hal yaitu kondisi sosial dan adil. Dua hal inilah yang menjadikan poligami akan menuai perdebatan dalam pemosisiannya, apakah dibolehkan dengan bersyarat atau malah dilarang.

Jika kita tinjau konteks turunnya ayat tersebut bahwa latar belakang historis diturunkannya ayat tersebut adalah berkenaan dengan harta anak yatim piatu. Mereka yang mengurursi harta anak yatim diingatkan oleh Allah, jika ingin menikahi anak asuhnya yang yatim maka hendaknya dengan I'tikad yang baik dan adil. Hal ini terutama kaitannya dengan pemberian mahar dan hak-hak lainnya terhadap perempuan yang dinikahinya. Wali tidak diperkenankan menikahinya hanya ingin mengambil hartanya. ${ }^{52}$ Belum lagi jika kita kaitkan dengan pernikahannya nabi Muhammad Saw, pada dasarnya beliau mengejarkan kepada umatnya untuk bermonogami, terbukti sampai usia 50 tahun rasulullah hanya memiliki seorang isteri yaitu khadijah. Adapun penikahan setelah itu beliau berprinsip pada dasarnya sebagai tt), h. 3

${ }^{52} \mathrm{Abu}$ Ja'far al-Ṭabarī, Tafsīr al-Ṭabarī, Juz 7 (al-Maktabah al-Syamilah, 
dakwah Islam bukan yang lain. ${ }^{53}$ hal ini terbukti dari 11 kali beliau menikah hanya siti aisyahlah yang perawan selain dia janda yang mempunyai anak. Semua itu rasulullah lakukan sebagai respon terhadap situasi perpolitikan dan system kesukuan. ${ }^{54}$ misi berpoligaminya nabi lebih pada kepentingan pendidikan (alta'limiyyah), penetapan hukum (al-tasyriiyyah), kemasyarakatan (al-ijtimaiyyah), dan perpolitikan (al-siyasiyyah). ${ }^{55}$

Beberapa hadits juga menjelaskan bahwa ayat ini berkaitan dengan wali yang menginginkan menikahi anak asuhnya yang anak yatim piatu, diantaranya

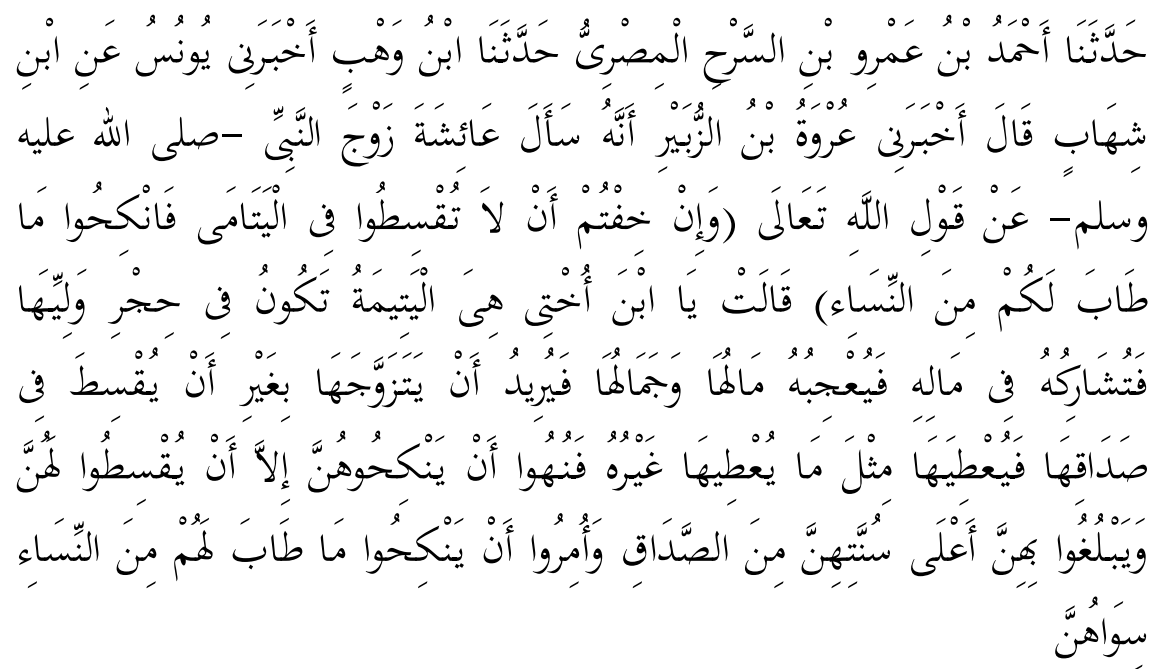

Artinya: "Telah bercerita kepadaku Ahmad Ibn Umar Ibn al-Yasar alMishriy, Ibn Wahab Bercerita kepadaku, Yusuf mengabarkan kepadaku dari Ibn Syihab, dia berkata : Urwah Ibn al-Zubair mengabarkan kepadaku bahwa ia bertanya kepada Aisyah isteri Nabi tentang firman Allah (wa in hiftum an laa tuqsituu fi al-yatama fankihuu ma thabalakum mina al-nisa'I matsna wa tsulasa wa ruba') Aisyah berkata wahai anak laki-lakinya saudara perempuanku, hal itu adalah anak-

${ }^{53}$ M. Alfathih Suryadilaga, "Sejarah Poligami dalam Islam" dalam Jurnal Musawa, Vol. 1. No. 1, (Maret, 2002), h. 13

${ }^{54}$ Zaitum Muhammad Kasim, Islam and Polygamy, (cet. ke-1; Selangor: Sister in Islam, 2002), h. 4

${ }^{55}$ Muhammad Musfir Husain al-Zahraniy, Nazrah fī Ta'addud al-Zaujāt, (cet. ke-2; Riyadl: Maktabah al-Taubah, 1991), h. 105-111. 
anak yatim yang dalam asuhan walinya, kemudian wali itu menjaga hartanya, pada suatu saat ia menginginkan harta dan terpesona kecantikannya sehingga dia ingin untuk menikahinya dengan tanpa berlaku adil untuk maharnya, kemudian ia memberikan mahar setara dengan apa yang umumnya berlaku, maka cegahla pernikahannya kecuali jika dia mampu untuk berlaku adil kepadanya dan memenuhi paling luhurnya maskawin dan perintahkanlah suapaya dia menikahi wanita-wanita selain dia yang dia senangi. ${ }^{p 56}$

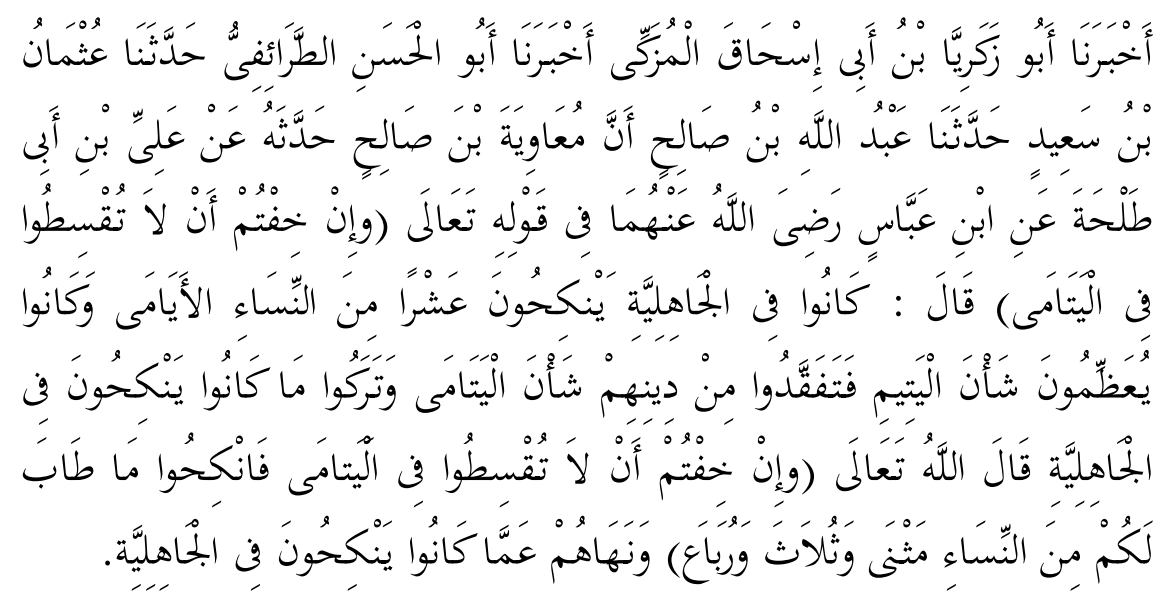

Artinya: "Abu Zakaria Ibn Abi Ishaq al-Mugzi telah mengabarkan kepadaku, Abu Hasan al-Tharaifi mengabarkan kepadaku, Utsman Bin Said mengabarkan kepadaku, Abdullah Bin sholeh mengabarkan kepadaku bahwa Muawwiyah Ibn Shalih mengabarkan dari 'Ali Bin Abi Thalhah dari Ibnu Abbas RA tentang firman Allah ta'ala (wa in hiftum an laa tuqsituu fi al-yatama) dia berkata ketika masa jahiliyyah orangorang menikahi 10 wanita yatim, mereka mengagumkan sesukanya, mereka mencari prinsip keagamaan kepada wanita yatim sesuai kehendaknya dan mereka meninggalkan penikahan model jahiiyyah sesuai firman Allah (wa in hiftum an laa tuqsituu fi al-yatama fankihuu ma thabalakum mina al-nisa'I matsna wa tsulasa wa ruba') Allah melarang kepada mereka model pernikahan masa jahiliyyah. ${ }^{57}$

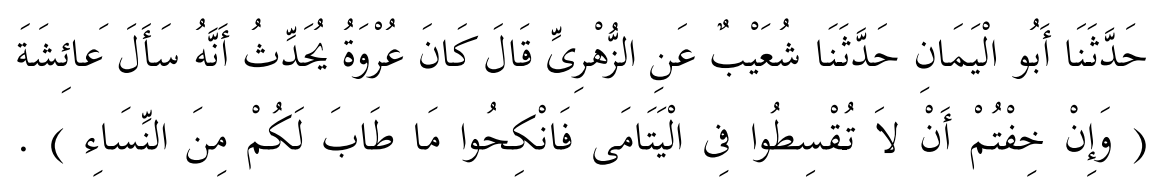

${ }^{56}$ Sulaiman Ibn al-Asy'ats Ibn Syadad Ibn Umar al-Azdiy Abu Daud alSajastaniy, Sunan Abu Daud, Juz 6 (al-Maktabah al-Syamilah, t.th.), h. 255

${ }^{57} \mathrm{Abu}$ Bakar Ahmad Ibn al-Husain Ibn 'Aliy al-Baihaqiy, Sunan Baihaqī, Juz: 2 (al-Maktabah al-Syamilah, t.th.), h. 146 


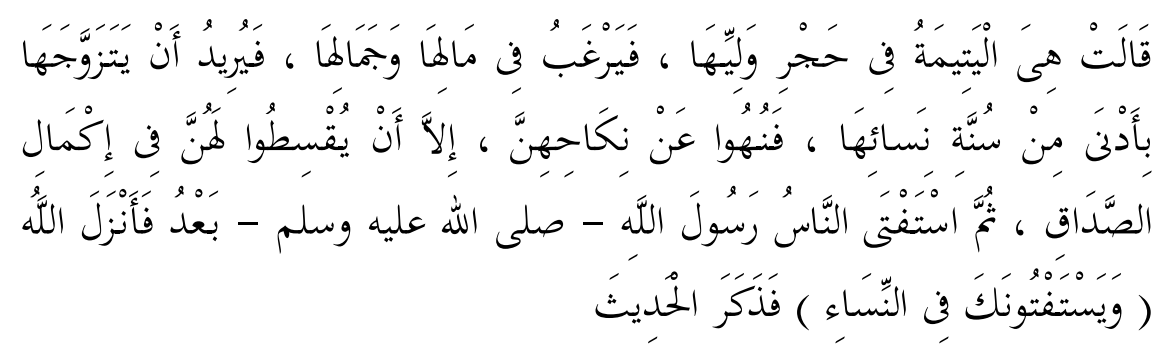

Artinya: "Abu al-Yaman mengabarkan kepadaku, Syuaib dari al-Zuhry mengabarkab kepadaku, ia berkata Urwah bertanya kepada Aisyah tentang firman Allah (wa in hiftum an laa tuqsituu fi al-yatama fankihuu ma thabalakum mina al-nisa'i ) Aisyah berkata dia adalah anak-anak yatim yang dibawah asuhan walinya, kemudian wali tersebut tertarik kepada harta dan kecantikannya, sehingga ia menginginkan untuk menikahinya dengan paling rendah maskawinnya, sehingga mereka dilarang menikahinya kecuali mereka mampu berlaku adil dalam pemberian maskawinnya, kemudian para manusia meminta fatwa dari Rasulullah, kemudian turunlah ayat tersebut. ${ }^{58}$

Menjadi jelas bahwa spirit poligami pada masa itu adalah berkaitan dengan masa depan anak yatim sebagai misi penjagaan hartanya. Dengan meniatkan poligami sebagai tolong menolong maka tidak salah poligami pada saat itu memperoleh kemudahan.

Kemudian tentang adil yang menjadi persyaratan selanjutnya, berdasarkan penilaian hadits di atas bahwa adil di sini menyangkut mahar, nafaqah, dan waktu menginap. Tidak ada sangkut pautnya dengan rasa cinta dan kasih sayang. Rasa cinta dan kasih sayang itu sulit sekali untuk diperhitungkan sehingga Islam memberikan kelonggaran bagi pelaku poligami untuk berlaku adil dari segi dhahirnya saja.

Menjadi jelaslah ketika adil lebih ditekankan pada hal-hal yang sifatnya dhahir tidak pada masalah cinta dan kasih sayang maka posisi poligami dalam Islam berspirit bukan nafsu melainkan rasa belas kasihan dan pertolongan. Sebagaimana Allah menerangkan masalah cinta kepada para isteri, yaitu surat al-nisa'(4) : 129

${ }^{58}$ Muhammad Isma'il Ibn Ibrahim Ibn al-Mughirah al-Bukhariy, Șahih alBukhārī, Juz 23, (al-Maktabah al-Syāmilah, t.th.), h. 88 


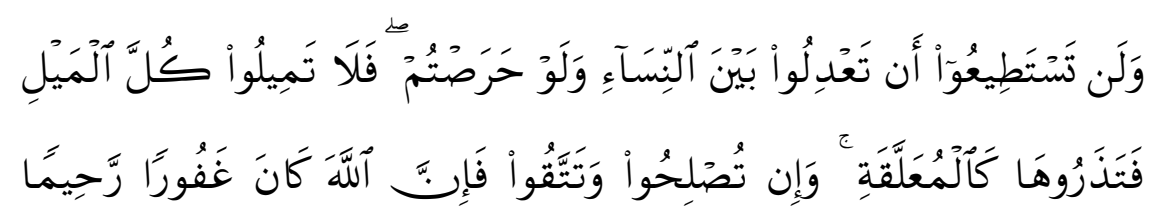

Artinya: "Dan kamu sekali-kali tidak akan dapat Berlaku adil di antara isteri-isteri(mu), walaupun kamu sangat ingin berbuat demikian, karena itu janganlah kamu terlalu cenderung (kepada yang kamu cintai), sehingga kamu biarkan yang lain terkatung-katung. dan jika kamu Mengadakan perbaikan dan memelihara diri (dari kecurangan), Maka Sesungguhnya Allah Maha Pengampun lagi Maha Penyayang."

Ayat ini menegaskan bahwa seorang laki-laki tidak akan mampu untuk berlaku adil dalam masalah cinta dan kasih sayang yang berhubungan dengan hati. Spirit laki-laki yang beristeri lebih dari satu yang berlandakan cinta akan menuai hasil yang tidak menggembirakan. Pernikahan yang bertujuan sakinah, mawadah, wa rahmah tidak mungkin tercapai jika isteri sudah dalam posisi tidak menuai cinta dan kasih sayang. Perempuan mudah goyah yang kemudian diibaratkan seperti muallaqah (terkatung-katung) ${ }^{59}$ dia merasa bahwa dirinya tidak mempunyai status, dikatakan mempunyai suami tetapi pada kenyataannya suami tidak memperhatikannya, dikatakan menjanda tapi kenyataanya dia belum tertalak oleh suami. Menjadi tertutuplah tujuan pernikahan yang menginginkan sakinah, mawadah, wa rahmah.

Dari uraian di atas pemosisian poligami di dalam Islam adalah sangat special. Keberadaan poligami tidak serta merta menjadi ada atau dibolehkan tanpa adanya inti pesan yang ingin

\footnotetext{
${ }^{59}$ Para ahli tafsir menjelaskan muallaqah itu sebagai la aiman wala dzati ba'lin (statusnya tidak janda dan juga mempunyai suami), lihat Abu al-Hasan 'Aliy Ibn Muhammad Ibrahim Ibn 'Umar al-Syaihiy, Tafsir al-Khazin, Juz: 5 (alMaktabah al-Syamilah, tt) Hal. 129, dalam redaksi lain muallaqah itu adalah la dzati zaujin wa la muthlaqatin (tidak mempunyai suami dan tidak pula tertalak), lihat Abu al-Fada' Isma'il Ibn Umar Ibn Katsir al-Quraisy alDimsyiqiy, Tafsir Ibnu Katsir, Juz: 2 (al-Maktabah al-Syamilah, tt), h. 128
} 
disampaikan yaitu berupa pesan kemanusiaan dan peribadahan. Poligami yang dilatar belakangi ta'aquli yaitu berupa alasan cinta maka tidak bisa dibenarkan, berbeda dengan poligami yang bermuatan ta'abuddi yaitu berniat untuk menolong tanpa adanya tendensi yang lain maka poligami berposisi sebagai suatu hal yang special. Oleh karena itulah pada era sekarang sangat minim sekali poligami untuk menduduki posisi yang special dimana peran wanita tidak bisa dinomor duakan, kebanyakan wanita banyak yang mandiri tanpa sokongan dari suami, segi keamanan juga sangat menjamin, belum lagi banyak masyarakat yang sudah melek hukum sehingga perilaku poligami tidak lagi dipandang sebagai solusi malah sebagai "sensasi" yang sering menjadi omongan masyarakat. Untuk itulah pada era sekarang poligami sulit untuk direalisasikan untuk kalangan umum. Alas an kemandulan seorang isteri bisa diselesaikan dengan mengadopsi anak dari kalangan miskin/yatim-piatu, benyaknya jumlah perempuan dibanding laki-laki dipertanyakan mengenai perbandingan wanita subur dengan monopouse. Berbeda ketika posisis poligami itu ada di daerah yang terkena bencana, maka spirit kemanusiaan dan tolong menolong mejadi sangat terbuka untuk menjadi alasan berpoligami.

\section{PENUTUP}

Poligami dalam konteks perundang-undang baik itu di Indonesia, Malaysia, Negara-negara yang mayoritas Islam di Asia maupun di Afrika berbeda-beda dalam memposisikan status poligami. Posisi poligami dapat dirangkas yaitu:

- Ada yang melarang poligami secara mutlak seperti Turki, Lebanon, dan Tunisia.

- Ada yang memberikan hukuman bagi yang melanggar aturan tentang Poligami seperti Tunisia, Iran, Irak, Mesir, Pakistan, Indonesia, dan Malaysia.

- Poligami harus mendapatkan izin dari pengadilan yaitu Syiria, Irak, Pakistan, Banglades, Somalia, dan Indonesia. 
- Poligami menjadi alasan cerai seperti Maroko, Lebanon, Syiria, dan Mesir.

- Dan poligami boleh secara mutlak yaitu Aljazair.

Poligami dalam tinjauan fiqih boleh jika memenuhi dua persyaratan yaitu mampu dalam segi materi dan adil selain itu ada sebab-sebab tertentu yang dibolehkan poligami yaitu sebab khusus dan umum yang secara garis besarnya mengacu pada dharurat, hajat, dan kemashlahatan.

Spirit poligami yang utama adalah kemanusiaan dan tolong menolong, sehingga pemberlakuan poligami khususnya pada era sekarang harus disesuaikan dengan konteksnya.

Pertimbangan bahwa status poligami hanya sebagai media sosial menjadikan poligami tidak serta merta dibolehkan, khususnya di Indonesia. Indonesia yang menganut poligami dengan bersyarat masih saja dalam kenyataannya poligami tidak memperoleh perhatian yang semestinya. Bisa dikatakan bahwa poligami di Indonesia "ada tapi tidak ada" maksudnya dalam perundang-undangan dengan jelas mengaturnya akan tetapi pada realita yang ada dimasyarakat praktek-praktek poligami cenderung tidak terkontrol oleh pemerintah. Banyak praktek poligami yang menuai kecaman karena tidak sesuai prinsip dasar pernikahan sehingga jangan heran pada saat orang baik-baik yang melakukan poligami seperti A A Gyim menuai kecaman publik. Rakyat menjadi trauma dengan dampak negative dari poligami yang illegal sehingga apapun status poligami mayoritas masyarakat menilai sebagai hal yang tragis.

Untuk itulah peran pemerintah harus lebih menekankan pada pemahaman poligami yang menuai kemashlahatan. tidak terfokus pada penilaian dari kalangan-kalangan tertentu yang lebih menekankan kehendak subyektif bukan obyekt'

\section{DAFTAR PUSTAKA}


al-Azdy, Sulaiman Ibn al-Asy'ar Abu Dawuda al-Sajastaniy, Sunan Abu Daud, al-Maktabah al-Syamilah, tt.

al-Baihaqiy, Abu Bakar Ahmad Ibn al-Husain Ibn 'Aliy, Sunan Baihaqiy, al-Maktabah al-Syamilah, tt.

al-Bukhariy, Muhammad Isma'il Ibn Ibrahim Ibn al-Mughirah, Shahih Bukhari, al-Maktabah al-Syamilah, tt.

al-Dimsyiqiy, Abu al-Fada' Isma'il Ibn Umar Ibn Katsir al-Quraisy, Tafsir Ibnu Katsir, al-Maktabah al-Syamilah, tt.

al-Ghazi, Ibnu Qasim, Fathul al-Qarib al-Mujib, al-Maktabah alSyamilah, tt.

al-Syafi'i, Muhammad bin Idris, al-Umm, al-Maktabah alSyamilah, tt.

al-Syaihiy, Abu al-Hasan 'Aliy Ibn Muhammad Ibrahim Ibn 'Umar, Tafsir al-Khazin, al-Maktabah al-Syamilah, tt.

al-Thabary, Abu Ja'far, Tafsir al-Thabari, al-Maktabah al-Syamilah, tt.

al-Quzwainy, Abu Abdillah Muhammad ibn Yazid, Sunan Ibnu Majjah, (al-Maktabah al-Syamilah, tt.

al-Zahraniy, Muhammad Musfir Husain, Nadhratun fi Ta'addudu al-Zaujaati, Riyadl: Maktabah al-Taubah, 1991.

al-Zuhaily, Wahbah, al-Fiqhu al-Islam wa Adillatuhu, Daru alFiqri,Suriah Dimsyiq, 1985

http://indonesia.faithfreedom.org/forum/dosen-al-azhar-mesirada-poligami-bukan-ajaran-Islam-t31730/

http://gagasanhukum.wordpress.com/2010/03/22/perempuaniran-menentang-poligami/

http://wikiberita.net/poligami-di-turki-dan-tunisia-sudahdihilangkan.html 
Kasim, Zaitum Muhammad, Islam and Polygamy, Selangor: Sister in Islam, 2002.

Mustafa Khan, Mustafa al-Bighā dan Ali al-Syarbaji, Al-Fiqh alManhajiy 'alā Mażhab al-Imām al-Syafi' '̄, Juz 1, al-Maktabah al-Syamilah, t.th.

Mahmud, Tahir, Family Law Reform in the Muslim World, New Delhi: N.M. Tripathi Pvt. Ltd, 1974

Nasution, Khairuddin, Hukum Perdata (Keluarga) Islam Indonesia dan Perbandingan Hukum Perkawinan di Dunia Muslim (Studi Sejarah, Metode Pembaharuan, dan Materi) dan Status Perempuan Dalam Perundang-Undangan Perkawinan Muslim, Yogyakarta: ACAdeMA dan TAZZAFA, 2009.

Suryadilaga ,M. Alfathih, Sejarah Poligami dalam Islam dalam Jurnal Musawa, Vol. 1. No. 1, (Maret, 2002)

Syahrur,Muhammad, Nahw Ușūl Jadīdah li al-Fiqh al-Islāmī Fiqh Mar'ah (Al-Wașiyyat, al-Irś, al-Qawāmah, al-Ta'addudiyyah, al-Libās), Suriyah: Maktabah al-Asad, 2000. 